\title{
A review of scientific research on the implementa- tion of traditional medicine in rehabilitation
}

\section{Osvrt na naučna istraživanja o primeni tradicionalne medicine u rehabilitaciji}

\author{
Slađana Arsic,, ${ }^{1}$ Dragana Kljajic, ${ }^{2}$ Marija Trajkov, ${ }^{2}$ Stevan \\ Jovanovic, ${ }^{2}$ Mile Despotovic ${ }^{1}$ \\ 1. College of Applied Health Sciences Cuprija, Ćuprija, Serbia \\ 2. High Medical School of Professional Studies, Zemun, Serbia
}

RECEIVED 27.10.2017

ACCEPTED 08.01.2018

\begin{abstract}
Traditional medicine (TM) is an expression used for a part of alternative medicine or medicine that is grounded on a folk knowledge. Regardless of the official position of the medicine, the use of methods of traditional medicine is constantly increasing, especially in the most developed countries. For example, $70 \%$ of the population in Canada and $80 \%$ in Germany are using some form of alternative or complementary medicine. In traditional medicine, the emphasis is on balance or "harmony" in the body, since the body is associated with the earth and the cosmos which is very important for the healing process. There are contrary opinions that claim that TM is a huge collection of never proven theory. A new way of looking and interpreting of all the evidence and observations about the processes of sickness and health is necessary for proving TM. There are enormous differences between TM and conventional medicine, both in the methods used for any kind of intervention and in the way doctors and healers are trained. It is also important to note that studies in the field of TM are using norms and standards used for research in conventional medicine, which means that they are not adapted to the basic characteristics of TM. Therefore, scientific research on the importance of using TM is a continuous process. The presented research results demonstrate the positive effects of the use of TM methods in rehabilitation.
\end{abstract}

Key words: medicine, traditional; complementary therapies; rehabilitation.

\author{
Sladjana Arsić, ${ }^{1}$ Dragana Kljajić, ${ }^{2}$ Marija Trajkov, ${ }^{2}$ Stevan \\ Jovanović,', Mile Despotović ${ }^{1}$ \\ 1. Visoka medicinska škola strukovnih studija, Ćuprija, Srbija \\ 2. Visoka medicinska škola strukovnih studija, Zemun, Srbija
}

PRIMLJEN 27.10.2017

PRIHVAĆEN 8.1.2018.

\section{APSTRAKT}

Tradicionalna medicina (TM) je izraz koji se koristi za deo alternativne medicine ili medicine koja proizilazi iz narodnog znanja. Bez obzira na zvanični stav medicine, primena metoda tradicionalne medicine je $\mathrm{u}$ stalnom porastu, posebno u najrazvijenijim zemljama. Na primer, 70\% stanovništva u Kanadi i 80\% u Nemačkoj koristi neki od oblika alternativne ili komplementarne medicine. U tradicionalnoj medicini naglasak je na ravnoteži ili „harmoniji“ u telu, jer je telo povezano sa zemljom i kosmosom što je veoma važno za proces lečenja. Postoje i suprotna mišljenja koja tvrde da je TM ogromna kolekcija nikada dokazanih teorija. Ono što je potrebno za njeno dokazivanje je novi način posmatranja i tumačenja, svih dokaza i zapažanja o procesima bolesti i zdravlja. Postoje ogromne razlike između TM i konvencionalne medicine, kako u metodama koje se koriste za bilo kakvu intervenciju, tako i u načinu na koji su lekari i iscelitelji obučeni. Značajno je i to da se za istraživanja u oblasti TM, koriste norme i standardi koji se koriste i za istraživanja u konvencionalnoj medicini, što znači da nisu prilagođena osnovnim karakteristikama TM. Zbog toga naučno istraživački rad o značaju primene TM, zahteva jedan kontinuirani proces u kome će učesnici iz različitih okvira, potpuno nepristrasno a u skladu sa rezultatima dobijenih istraživanja donositi zaključke. Rezultati prikazanih istraživanja pokazuju pozitivne efekte kod primene metoda TM u rehabilitaciji.

Ključne reči: medicina; tradicionalna; komplementarne terapije; rehabilitacija. 


\section{INTRODUCTION}

Traditional medicine (TM) is an expression used for a part of alternative medicine or medicine that is grounded on a folk knowledge. Complementary and alternative medicine (CAM) is an acronym most commonly used by the professional public. It refers to a number of different health care forms that are applied in practice, but not as a part of the tradition of that country not integrated into the dominant health care system. ${ }^{1}$ Traditional medicine uses ancient therapies that are inherent in certain cultures. Complementary medicine primarily points to the possibility to use certain complementary systems as a supplement to therapeutic procedures in the official medicine. The basis of alternative medicine is on therapeutic systems and methods that are based on a different vision of the world and human beings. ${ }^{2}$

The use of methods of traditional medicine is constantly increasing, especially in the most developed countries such as Germany, Canada, France, Australia, the USA and Great Britain. The reasons for the increase in popularity of traditional medicine are complex and not fully explored. ${ }^{3}$ The popularity of various disciplines of traditional medicine continues in the 21st century. In some Asian and African countries, up to $80 \%$ of the population is using the services of traditional medicine in primary healthcare during the last thirty years. ${ }^{4}$ In addition, an interest in the traditional medicine in many developed countries is significantly increased. For example, $70 \%$ of the population in Canada and $80 \%$ in Germany are using some form of alternative or complementary medicine. The prevalence of traditional medicine application has increased in Ireland from $20 \%$ in 1998 to $27 \%$ in 2002. Similar data were obtained at the international level. The greatest number of Irish people have practiced the methods of traditional medicine for severe pain, anxiety or depression. ${ }^{5}$

The global economic crisis at the end of the first decade of the 21st century and many unresolved problems in health care have given the possibility to users of health services to choose from the available treatment methods, that is, from the traditional methods of treatment. The National Center for Complementary and Alternative Medicine (NCCAM) states that approximately $38 \%$ of adults and $12 \%$ of children are using traditional therapeutic methods in pain treatment today. Up to 34 billion dollars are spent annually on alternative therapies in America. ${ }^{6}$

Federal research conducted in the United States in 2007 found that almost 5 million Americans were using homeopathic medicinal products made from substances such as duck liver, heavy metals, and various extracts of plants, dissolved in water to undetectable levels.7 Unlike vaccines or medicines that are dispensed by prescription only and must have a clear declaration of the composition and relevant characteristics, homeopathic medicines, which are sold for more than 200 million dollars annually in the US, according to official data, usually do not provide information about their safety and side effect and generally are not labeled with a list of ingredients and information about the terms of use. Despite the lack of evidence on the validity of homeopathic drugs, an increasing number of Americans, as stated in the survey conducted by the Washington Post, are using these drugs many diseases, while in the meantime, there is an aggressive worldwide campaign against food and medicines without a license or an evidence on their effectiveness in the treatment of diseases. ${ }^{7}$

In traditional medicine, the emphasis is given to balance and "harmony" in the body. The body is connected to the earth and the cosmos, which is very important in the healing process. Therefore, there is a belief in traditional medicine that the disease should be treated with all resources available. Herbal preparations, prayer, diet, exercise, and proper social relationships are sustainable means in an attempt to preserve health. ${ }^{8}$

Historically speaking, both awareness of the existence of different attitudes towards health and the belief in the experiences of those who use the traditional approach to treatment, have great importance for public health and its practice in the 21 st century. It is necessary to dismiss the condemnation of those who use this approach, especially when it is known that today's medical practice works efficiently by applying various methods of traditional medicine. ${ }^{9}$

General guidelines of the WHO (General Guidelines for Methodologies on Research and Evaluation of Traditional Medicine) are primarily focused on the safety and efficacy of traditional medicine, with the aim to provide answers to questions concerning the basic evidence of the validity of certain methods of traditional medicine. ${ }^{9}$ 


\section{DISCUSSION}

Propnents of traditional medicine claim that the basis of the functioning of traditional medicine is in the balance of two mutually opposite forces, yin and yang. Yin is the personification of the cold, slow and passive principle, and yang is the representative of hot, excited and active principle. The basic assumption, according to the understanding of traditional medicine, is that health is achieved by maintaining a relation balance between yin and yang. The imbalance between yin and yang leads to disruption of the flow of vital energy qi (chi) and blood along the channels known as meridians. Therapeutic procedures based on the use of herbs, acupuncture and massage, should help to establish the flow of qi (chi) and blood along the meridians, thus achieving balance and healing of the body ${ }^{10}$ In order to prove this, a new way of seeing, reasoning and interpretation is needed. However, there are phenomena that cannot be explained completely by contemporary biomedical science. Traditional medicine is not a biomedical science it is more an art and a skill of treating patients. ${ }^{10}$

Medicine has not confirmed the hypothesis about the concept of outbreaks of a disease caused by the imbalance of yin and yang energy or the congestion of chi energy considering that there are no instruments, nor even units of measure to quantify this energy. Anatomy and histology have shown that the blood moves through the veins, arteries, and capillaries. They have mapped their position within the human body and found no additional meridians through which the blood could move nor the channels through which the chi energy could move. Contemporary therapists of traditional Chinese medicine present these meridians as assumptions that are useful in clinical practice. ${ }^{10}$

Therefore, in his researches, dr. Edzard Ernststates, that the evidence on the effects of acupuncture have low credibility and that some of acupuncture experts use the word "trial" or "possible" increasingly due to a lack of clear evidence. Contrary to these studies, there are some recent researches on the acupuncture principles, which indicated the existence of electrical nerve excitability at the acupuncture points, by whose provocation the secretion of endorphins and oxytocin achieved, further relieving a pain, with simultaneous activation of the other parts of the brain. Other effects of acupuncture are explained by the functioning of these systems, too. ${ }^{11}$

As a medical system, naturopathy was established in America in the late 19th century on the basis of European traditional medicine. It is based on the understanding that the disease is a manifestation of an altered organism process, which otherwise heal themselves, by their very nature. Naturopathy is the most practiced in the United States, Europe, Canada and Australia. ${ }^{12}$

German physician Samuel Hahnemann, was a doctor who laid the foundations of a new method of treatment Homeopathy. Starting from the assumption that every organism possesses the inborn self-healing ability, and that treatment should not be composed of symptoms removing rather than stimulation of body's "internal forces" of self-healing, Hahnemannhas derived the basic principles of homeopathy. ${ }^{13}$

The subject of numerous studies was "the interaction of mind and body". Mind-body medicine is based on the interaction of brain and body functions, with an influence of personality, emotional, mental, social, spiritual and behavioral factors on the health status of man. Procedures of the mind-body medicine that promote health include relaxation, hypnosis, visual imagination, yoga, meditation, biofeedback, tai chi, qi gong, cognitive-behavioral therapy, group support, autogenic training, spiritualism, and prayers. Results of clinical studies have shown the beneficial effects of practicing in some diseases as well as cognitive-behavioral interactions and hypnosis, with clear evidence of physiological effects. ${ }^{14}$ Practicing these therapies improve mood and quality of life of cancer patients who are receiving chemotherapy, reducing nausea, disgust, and vomiting. ${ }^{15}$ By using the mind-body medicine methods, susceptibility to respiratory infections influenced by stressors is reduced while the immunological parameters are improved. ${ }^{16}$ Techniques and procedures of the mind-body medicine are the most common type of traditional medicine in recent years. About 30\% of the adult US population practice different relaxation techniques like autogenic training, hypnosis, and visual imagination, while approximately $50 \%$ of Americans use meditation and prayer. ${ }^{16}$

Mind-body medicine considers a disease as a form of personal overcoming, development, and transformation, and that the therapist serves as a catalyst and a guide in the process. The basis for the use of alternative therapeutic procedures offered by mind-body medicine consists of the results of numerous clinical trials that have found that there are mechanisms by which the brain affects the immune, endocrine, and autonomic functions, and they have a significant influence on health and disease. ${ }^{17}$

The combinations of "relaxation techniques" and "behavioral-cognitive interventions" aimed at overcoming of stress are suitable particularly for additional treatment of 
ischemic coronary diseases and arthritis. When combined with "educationally-informational components", these techniques give good results as an additional treatment and palliative treatment of chronic diseases. ${ }^{14}$ The great technological progress of science and the use of modern diagnostic have caused that physicians are more concerned about a disease than a patient. This leaves a lot of space for the use of traditional medicine in treatment because traditional medicine is primarily concerned with a patient, and then with a disease..$^{16}$

The question is whether dealing with a patient could lead to healing or maybe only a placebo effect is present. A placebo effect occurs by both cognitive mechanisms, and mechanisms of automatic practicing. A research study, in which positron emission tomography of the brain was applied, found that patients with Parkinson's disease, as a response to placebo, released the neurotransmitter dopamine. The release of dopamine was well expressed and mediated through the activation of nigrostriatal dopaminergic system, which is damaged in Parkinson's. These results show that a placebo effect is mediated by the formed autonomous reaction that involves the releasing of dopamine, which has a strong impact on the functioning of the neural network, and that could be helpful in the treatment of patients with Parkinson's disease. ${ }^{17}$

Dietary supplements are products whose active ingredients can help, amplify or assist in strengthening the natural functions of the body. The U.S. Office of Dietary Supplements defines a dietary supplement as a product that is intended to supplement the diet and contains one or more of the following components: vitamins, minerals, herbs and other herbal products, amino acids, dietary substances that positively affect food intake, concentrates, metabolites, extracts, or various combinations of these components. ${ }^{18}$ There has been a significant increase in interest of people worldwide for the use of dietary or nutrition supplements by the end of the 20th century. Thus, herbal products trade has reached a level of 5.3 billion dollars in Europe only. The increasingly aggressive advertising campaign of manufacturers of dietary supplements has contributed to such an interest. ${ }^{19}$

Numerous techniques that are based on the body manipulation have origin in traditional medicine of China, India, and Egypt, but some, such as chiropractic and osteopathy, were developed in the early 20th century in the USA. The main principles of these techniques are based on the manipulation of specific organ systems of the body, such as musculoskeletal system, circulatory system, and lymphatic system. Regardless of the fact that these techniques are widely used, they have not yet reached the level of being recognized as a scientific discipline equal to classic medicine. In many studies listed the positive effects of manipulative techniques and points to their safety. Positive effects of manipulative techniques are listed and their safety indicated in many studies. Clinical studies show that spinal manipulative techniques are not efficient when it comes to the treatment of high blood pressure, asthma, and dysmenorrhea, but that they have a positive effect in the treatment of a migraine, tensiontype headaches and weak short-term effect in persons with neck pain. ${ }^{20}$

Valizadeh and associates have compared the effects of the application of foot reflexology and the application of hot footbath, as well as their impact on sleep quality in elderly people. Based on the previous studies, it is believed that $67 \%$ of elderly people have a sleep disorder. The aim of this study was to examine whether sleep quality could be improved without the use of pharmacological therapy. The effects of two aforementioned applied methods, were compared at the same time. The study was conducted on 69 participants, male persons, for a six weeks period. Reflexology was applied once a week while the hot baths were applied continuously for an hour before sleeping in participants from the control group. Participants from the experimental group had both therapies continuously, every day. The results showed that sleep quality was significantly improved in all the participants by applying reflexology and hot baths, but research also found that there was no statistically significant difference between the effects of the application of reflexology and hot baths on the quality of sleep. According to these results, they had exactly the same impact on the quality of sleep. The use of non-pharmacological methods, reflexology and hot baths, to improve sleep quality is proposed. It is believed that they should be included in a health program. In addition, it is proposed that future research should exclude subjective experience and explore the placebo effect on the quality of sleep. ${ }^{21}$

Nazari and co-workers have conducted a research study on the subject of comparing the effect of reflexology and relaxation application on fatigue in women with multiple sclerosis (MS). Fatigue is the most common and highly frequent symptom in patients with MS, and as such, it has negative effects on employment, the process of socialization and efficiency in the activities of daily living. The use of complementary and alternative medicine in patients with MS is higher than in the general population. However, there is no scientific evidence to support their effectiveness. Therefore, this study was aimed to show the efficacy and compare the effects of reflexology and relaxation on fatigue in women with MS. This clinical 
study was done on 75 patients with MS divided into three groups, each group consisted of 25 participants, in a way that one group received reflexology, and another group Jacobson's relaxation techniques. The control group received routine care and medical treatment according to a physician. The results show that there was no significant difference between groups in the fatigue measurement when assessed immediately after interventions, but two months after, the assessed fatigue scores were the lowest in the group that received reflexotherapy, but that there was no statistically significant difference between the group that received relaxation methods and the control group. The results show that both interventions had a positive impact on the fatigue reduction, but the effects of reflexotherapy on the fatigue reduction were significantly higher than the effects achieved through relaxation techniques. The results of this study support the implementation of reflexotherapy in the elimination of fatigue in patients with MS, and other than affordable, they are proven to be very effective. ${ }^{22}$

Among the most common complications of type 2 diabetes mellitus are arteriopathy and neuropathy of the lower extremities. These changes lead to the decrease of elasticity, which may further results in reduced mobility. In a large study conducted in England, Portugal and Spain, da Silva NC and colleagues have evaluated the effects of reflexology application on feet impairment already present in patients with type 2 diabetes mellitus. The sample consisted of 45 patients, and according to distribution, $65 \%$ of included patients were females. Groups were not homogeneous. In fact, significant differences in demographic characteristics and associated diseases were noted. Certain indicators related to the quality of skin and hair, blood circulation, and feet issue sensitivity were evaluated. The results indicate that those participants who received reflexology had better results in the assessed indicators. The positive effect of reflexology was reflected in the improvement of blood circulation and tissue temperature, or in other words, through improved circulation. ${ }^{23}$

Reflexology is a popular form of complementary and alternative medicine. The aim of this study was to analyze research studies and to critically evaluate the evidence for or against the application of reflexology, as well as to examine its effectiveness in patients with any type of medical condition. All clinical trials in reflexology were registered and identified within six electronic databases. Their methodological quality was rated by two independent reviewers, and 23 studies met all the conditions for inclusion in the study. A wide range of medical conditions was included. The results of nine studies showed negative findings, while the results of five studies generated positive findings regarding the application of reflexology. The results of eight studies showed that the application of reflexology proved positively in diabetes-mellitus, premenstrual syndrome, in multiple sclerosis, and in some patients with cancers. However, clinical evidence does not demonstrate convincingly that the reflexology is a fully effective treatment for any disorder or health status. ${ }^{24}$

Angela Del Rosso and associates have applied and described the effects of complementary therapies in clinical practice of Mind body therapies (MBT). It is a therapy that involves mental and physical dimensions and focuses on the relationship between brain, mind, body, and behavior and on their impact on health and disease. The greatest number of rheumatic diseases have a chronic course, which leads to progressive damage of musculoskeletal system and causes physical, psychological and social problems. Therefore, a rheumatic patient should be treated with a multidisciplinary approach. Application of MBT therapy may be useful in patients with rheumatoid arthritis, ankylosing spondylitis, and fibromyalgia syndrome. ${ }^{25}$

Obese persons are often insufficiently physically active. Telles S. and associates have investigated the effects of the application of yoga techniques and a diet change in obese persons with an emphasis on breathing techniques practiced while a person was sitting. The study included 47 participants whose body mass index, waist and hip circumferences, upper arm circumference, and hand grip strength were assessed, whereas the cholesterol levels were observed from laboratory findings. Participants were practicing yoga for five hours every day a day and were evenly distributed. The assessment was made after only six days and the results showed: a decrease in body mass index by $1.6 \%$, a reduction of waist and hips circumferences, decrease in total cholesterol by $7.7 \%$, and increase in hand grip. The results of this study indicate the positive effects of the application of yoga techniques and a diet change in obese persons, at the same time warning that an intensive program of yoga techniques with a diet change may have some risks. The question is whether it is possible to maintain the achieved results by continuous and less intensive treatment. ${ }^{26}$

Shirley Telles and associate have conducted a study about a published research on traditional medicine (TM) and an attempt to conform TM to the model of conventional medicine. Included research articles, certain critics and abstracts published in PubMed were review categorized as an experimental. ${ }^{27}$ Some of the papers specifically state that further studies are needed and that it would be acceptable to integrate TM into mainstream health care 
at the moment, once there is sufficient knowledge about the efficacy, safety, and mechanism of action of its methods. In addition to an inadequate and small sample, the following is mentioned insufficient statistics, deficient control, the inadequate control sample, absent description of the treatment or product, lack of comparisons with other treatments or with a placebo effect. The second level of difficulties in the preparation of the study is in the differences in the forms, approaches, and nature of treatment, making it difficult to clearly describe the application of TM methods. The absence of such standardization makes the research difficult. Great problem in research on the application and effects of TM is a placebo effect. The interaction between the healer and the patient, which is common in TM, may have a placebo effect. Furthermore, when it comes to intervention in which the patient is participating, such as chiropractic, massage, and acupuncture, it is difficult to assess the existence of a placebo effect. This is increasingly difficult when the patient is actively involved in the intervention, as is the case of practicing yoga techniques. Most of these techniques involve subtle mental changes, and therefore it is difficult to assess a placebo effect. ${ }^{27}$

Standardization in terms of training and implementation of TM is a great challenge. There are enormous differences between TM and conventional medicine, both in the methods, used for any kind of intervention and in the way the doctors and healers are trained. In order to enable the involvement of TM techniques in current conventional medicine, it is necessary to make the standards for training primarily and then for the practicing of TM technique. It is very important to define who delivers training and who is being trained, together with formation of the Commission for the assessment of quality training control and implementation. Studies on the training of personnel for the practicing of TM methods show that many persons trained for the use of TM have a deep faith in the system of healing. However, most of them are not educated in the meaning of conventional medicine. Therefore, it is very important that to conduct research on training and application of TM by those who are unbiased and medically trained. Nevertheless, those with medical education trained for the usage of TM adapt themselves to the needs of training, using TM. This raises the question of their bias, but this ives an ideal opportunity to conduct a research with them. Moreover, the manner of research which is to be conducted, and the application of certain norms and standards are more suitable for the studies in the field of conventional medicine. Consequently, many things from the TM field can be questionable, declaring obrained results unscientific For example, the existence of energy as the basic concept of the functioning of TM, can be misunderstood and scientifically unacceptable. It is believed that research in the field TM should be carried out by experts in the field of conventional medicine, with a good knowledge of TM, but who are not biased in their approach to interpret the results. In other research in TM, particularly related to the use of medicinal herbs in healing, concepts of conventional medicine are already in use $^{27}$.

\section{CONCLUSION}

The rise of modern information technologies leads to the raising of awareness of the importance of knowledge from the field of Traditional Medicine (TM). Therefore, scientific and research work about the importance of use of TM requires one comprehensive, continuous process in which participants from different frameworks, complete impartiality and in accordance with results from the obtained studies, make conclusions that will be the basis for new studies, but also for the safety of the use of current knowledge. The ultimate goal of the scientific researches in the field of TM is to come up with a standardized method for studying the TM, with sufficient information based on research of their efficiency, safety and mechanisms of action. 


\section{REFERENCES}

1. World Health Organization. Programme on traditional medicine. Geneva: World Health Organization, 2000 .

2. WHO Traditional medicine strategy: 2002-2005. Geneva: World Health Organization, 2002. (http://apps.who. int/medicinedocs/pdf/s2297e/s2297e.pdf).

3. Legal Status of Traditional Medicine and Complementary/Alternative Medicine: A Worldwide Review Geneva: World Health Organization, 2001. (http://apps.who. int/medicinedocs/pdf/h2943e/h2943e.pdf)

4. Aung HT, Sein MM, Aye MM, Thu ZM. A review of traditional medicinal plants from Kachin State, Northern Myanmar. Nat Prod Commun 2016; 11: 353-64.

5. Fox P, Coughlan B, Butler M, Kelleher C. Complementary alternative medicine (CAM) use in Ireland: a secondary analysis of SLAN data. Complement Ther Med 2010; 18: 95-103.

6. Richardson MA. Biopharmacologic and herbal therapies for cancer: research update from NCCAM. J Nutr 2001; 131(11 Suppl): 3037S-40S.

7. Owen-Smith A, De Padilla L, Di Clemente R. The assessment of complementary and alternative medicine use among individuals with HIV: a systematic review and recommendations for future research. J Altern Complement Med. 2011; 17: 789-96.

8. Huff R, Kline M. Promoting health in multicultural populations: a handbook for practitioners. Thousand Oaks: Sage Publications Inc., 1999.

9. Helman C G. Culture, health and illness: an introduction for health professionals. 3rd ed. Bristol: ButterworthHeinmann, 1994.

10. Kaptchuk TJ. Acupuncture: theory, efficacy, and practice. Ann Intern Med 2002; 136: 374-83.

11. Ernst E. Acupuncture - a critical analysis. J Intern Med 2006; 259: 125-37.

12. Smith MJ, Logan AC. Naturopathy. Med Clin North Am 2002; 86: 173-84.

13. Longe JL. The Gale encyclopedia of alternative medicine. Detroit: Thomson Gale, 2005.

14. Sancier KM, Holman D. Commentary: multifaceted health benefits of medical qigong. J Altern Complement Med 2004; 10: 163-5.

15. Mundy EA, Du Hamel KN, Montgomery GH. The efficacy of behavioral interventions for cancer treatmentrelated side effects. Semin Clin Neuropsychiatry 2003; 8: 253-75.
16. Viner R. Putting stress in life: Hans Selye and the making of stress theory. Soc Stud Sci 1999; 29: 391-410.

17. De la Fuente-Fernandez R, Phillips AG, Zamburlini $\mathrm{M}$, et al. Dopamine release in human ventral striatum and expectation of reward. Behav Brain Res 2002; 136: 359-63.

18. De Smet PA. Herbal medicine in Europe - relaxing regulatory standards. N Engl J Med 2005; 352: 1176-8.

19. Maličević Ž. Alternativna i komplementarna medicina. Vojnosanit Pregl 2006; 63: 55-64.

20. Astin JA, Ernst E. The effectiveness of spinal manipulation for the treatment of headache disorders: a systematic review of randomized clinical trials. Cephalalgia 2002; 22: 617-23.

21. Valizadeh L, Seyyedrasooli A, Zamanazadeh V, Nasiri K. Comparing the effects of reflexology and footbath on sleep quality in the elderly: a controlled clinical trial. Iran Red Crescent Med J 2015; 17: e20111. (doi: 10.5812/ ircmj.20111).

22. Nazari F, Shahreza MS, Shaygannejad V, Valiani M. Comparing the effects of reflexology and relaxation on fatigue in women with multiple sclerosis. Iran J Nurs Midwifery Res 2015; 20: 200-4.

23. da Silva NC, Chaves Éde C, de Carvalho EC, Carvalho LC, Iunes DH. Foot reflexology in feet impairment of people with type 2 diabetes mellitus: randomized trial. Rev Lat Am Enfermagem 2015; 23: 603-10.

24. Ernst E. Reflexology: an update of a systematic review of randomised clinical trials. Maturitas 2011; 68: 11620.

25. Del Rosso A, Maddali-Bongi S. Mind body therapies in rehabilitation of patients with rheumatic diseases. Complement Ther Clin Pract 2016; 22: 80-6.

26. Telles S, Naveen VK, Balkrishna A, Kumar S. Short term health impact of a yoga and diet change program on obesity. Medical Science Monitor 2010; 16: CR35-40.

27. Telles S, Pathak S, Singh N, Balkrishna A. Research on traditional medicine: what has been done, the difficulties, and possible solutions. Evid Based Complement Alternat Med 2014; 2014: 495635. (doi: 10.1155/2014/495635). 